\title{
A study of abundance of planktonic organisms in Lekan-Are Lake, Ogun State, Nigeria
}

\author{
N. B. IKENWEIWE ${ }^{1}$, A. O. DAVIES ${ }^{2}$ and A. A. IDOWU ${ }^{1 *}$ \\ ${ }^{1}$ Department of Aquaculture and fisheries Management University of Agriculture, P.M.B 2240, Abeokuta, \\ Ogun State, Nigeria. \\ ${ }^{2}$ Delta State University, Abraka, Nigeria. \\ *Corresponding author, E-mail: idowudoyin@yahoo.com
}

\begin{abstract}
A study of the plankton abundance in the shore, surface and bottom of Lake Lekan-Are Abeokuta, Ogun State, Nigeria was carried out between January 2007 and August 2008 at three stations along the entire stretch of the lake. The numerical abundance of the plankton in this lake was investigated. There were marked seasonal variations in the zooplankton and phytoplankton of the lake. Four major groups of phytoplankton were identified Baccilariophyceae (diatoms), Chlorophyceae (green algae) and Cyanophyceae (blue green). The green algae dominated the phytoplankton constituting $63.3 \%$ in the surface and $54.8 \%$ in the bottom zone of the lake. The phytoplankton density was at its peak in sunny months of January to early June that coincided with the period of high temperature. The three major groups of zooplankton observed in the lake were Cladocera, Copepoda and Rotifera. The Copepoda dominated the three habitats $83.37 \%$ (shore), $82.73 \%$ (surface) and $80.26 \%$ (bottom). Copepoda also dominated at the three stations of the lake. The seasonality of zooplankton followed a similar pattern with that of the phytoplankton reaching a peak between February and May.

() 2011 International Formulae Group. All rights reserved.
\end{abstract}

Keywords: Numerical abundance, plankton Lekan Area, Nigeria.

\section{INTRODUCTION}

Phytoplankton are plants (microscopic), drifting at the mercy of water current (Anene, 2003). They constitute the primary producers of aquatic ecosystems. They convert incident radiant energy of the sun to chemical energy in the presence of nutrients like phosphorous, nitrogen, iron, manganese, molybdenum and zinc. They are restricted to the aphotic zone where there is enough light for photosynthesis. The distribution, abundance and diversity reflect the physico-chemical conditions of aquatic ecosystem in general and its nutrient status in particular, Anene (2003).

Davies et al. (2009) have also reported that phytoplankton communities are major producers of organic carbon in large rivers, a food source for planktonic consumers and may represent the primary oxygen source in low-gradient Rivers (Ezekiel et al., 2011). Plankton are of great importance in biomonitoring of pollution (Davies et al., 2009). The distributions, abundance, species diversity, species composition of the plankton are used to assess the biological integrity of 
the water body (Townsend et al., 2000). Townsend et al. (2000) and Conde et al. (2007) reported that plankton communities serve as bases for food chain that supports the commercial fisheries.

Within the recent past decades, considerably interest has been taken in the relevance of limnological information, the productivity, development and management of the aquatic environment (Azionu, 2001). To date there has not been any work on the numerical abundance of plankton in this lake and this is the basis for this study.

\section{MATERIALS AND METHODS}

\section{Description of project Site}

Lekan Are dam is the second small/medium earth dam constructed by the Ogun-Osun River Basin Development Authority (O-ORBDA) in 1982, after the Eniosa dam Ojoo, Ibadan, Oyo state, Nigeria. The dam is located in the headquarters of the O-ORBDA at Alabata road off IbadanAbeokuta high way, Abeokuta Ogun State (OORBDA, 1998).

Lekan-Are dam is a multi-purpose earthen dam constructed across a small stream flowing through O-ORBDA's (Ogun-Osun River Basin Development Authority) headquarters site, with a capacity of $0.6 \mathrm{~cm}$. The dam has a spillway, one in-take house for a water treatment plant $(80 \mathrm{~m} 3 /$ hour or 900 Htres/min.), ground tank of 350,000 litres (75,000 gallons), overhead tank of 25,000 gallons $(115,000$ litres) and a network of distribution pipes of $2.5 \mathrm{~km}$ total length. The dam also provides water for irrigation of a 23 ha farm land for training and demonstration purpose at the Headquarters of Oorbda. It is also use for provision of portable water supply for the Headquarters' staff consumption and for commercial water bottling.

It has been stocked with fish species at different periods from its completion in 1982, and fishing activities at the shallow parts have been done yearly (during the dry season) by professional fishermen with the authority providing the boats and fishing gears while the fishermen use their expertise; and the capture is shared equally between the fishermen and the authority at the end of the exercise. Fish production from the dam in 2004 and 2005 were $214.8 \mathrm{~kg}$ and $108 \mathrm{~kg}$ respectively (personal communication). However there still exist huge stocks waiting to be exploited as the fishing activities that have been done in the reservoir has been at few selected shallow areas.

\section{Sampling procedures}

A stone with a rope (in meters) was first dipped into the lake water at the point where the water was to be collected, brought out and the depth was measured. This depth was divided into three so as to collect water samples at the shore, surface and bottom Surface water samples were collection from a depth of about 10 meters.

\section{Plankton sampling and enumeration}

The plankton samples were collected at each identified station from shore, surface and both depth by collecting water samples using a Van Dom Water sampler and was immediately fixed with $4 \%$ formalin. On arrival at the laboratory $100 \mathrm{ml}$ of each sample was poured into a measuring cylinder and $1.0 \mathrm{ml}$ of Lugol's solution was added. The treated sample was then left to stand for at least twenty-four (24) hours. Then the supernatant top $90 \mathrm{ml}$ was carefully decanted and the remaining $10 \mathrm{ml}$ was transferred into a test-tube chamber. A dropper was used in putting $1 \mathrm{ml}$ of this sample into a slide and was mounted on a microscope. The number of plankton per $\mathrm{ml}$ was counted and later multiplied by 10 so as to get accurate number of plankton in the $10 \mathrm{ml}$ sample. This was repeated thrice and the values from the three trials were added together and divided by three (the number of trials) to get the average 
per $\mathrm{ml}$ of water (per drop of water). All the plankters presents in this sub-sample were identified according to Ikenweiwe (2005).

The population was estimated accordingly, using the method of Ikenweiwe and Otubusin (2007).

Where $90 \mathrm{ml}$ of water was decanted from $100 \mathrm{ml}$ out of which $1 \mathrm{ml}$ of the sample was investigated under the microscope. Then the $10 \mathrm{ml}$ remaining contained all the plankters in the $100 \mathrm{ml}$ of water.

Therefore $10 \mathrm{x}$ Number of plankters in $1 \mathrm{ml}$ of the sample $=$ Population of plankters in the $100 \mathrm{ml}$ water: $(\mathrm{A})$ for 1 litre $=(\mathrm{A} \times 100)$.

\section{RESULTS}

\section{Phytoplankton}

The numerical density of the phytoplankton of Lekan Are is presented in Table 1. The Chlorophyceae dominated the phytoplankton community at the shore $(63.3 \%)$, surface $(56.0 \%)$ and bottom $(54.8 \%)$. The Bacillariophyceae are next to Chlorophyceae with $21.5 \%$ at the shore, 25.7 at the surface and $26.3 \%$ at the bottom. While Cynophyceae are the least observed with $15.2 \%$ at the shore, 18.3 at the surface and $18.9 \%$ at the bottom of the habitats. Generally in the entire lake, the Chlorophyceae dominated the entire population by $57.5 \%$ while Cyanophycae were the least $18.0 \%$. Table 2 shows that station 1 had the highest population (no/I) of Chlorophyceae (552) followed by station 2 (295) while station 3 had the least (156). At stations 1, 2 and 3, Bacillariophyceae populations dominated with ranges of $19.9-26.5 \%$ while Cyanophyceae were the least between, $6.3-21.90 \%$. The phytoplankton populations were at a peak in the month of January at station 1 (inlet) decreasing gradually through to the month of August when the population was least (Figure 1). The abundance increased gradually until another peak was reached in July then a decline in August. Table 3 further showed that the highest abundance of phytoplankton was recorded at the shore, surface and bottom of Station 1 compared to Station 3 where the least were recorded. From habitat to habitat, the bottom had the highest population of phytoplankton while the least was recorded at the shore (Table 1 and 2).

It was generally observed that the phytoplankton density was at its peak in the sunny month of January. The highest abundance of phytoplankton was recorded at the shore, surface and bottom of station 1 compared to station 3 where the least values were recorded.

\section{Zooplankton}

The numerical density of the Zooplankton of Lekan Are presented on Figure 2. Throughout the period of sampling, the Copepoda dominated in the three habitats: shore $(83.37 \%)$, surface $(82.73 \%)$ and bottom $(80.26 \%)$. This was followed by the Cladocerans (8.1-22.7\%) and the least group was the insect larvae $(0.0-0.4)$ at the three habitats. Comparing the three stations, the copepods still dominated at the three stations: Station $1(85.1 \%)$, station $2(82.7 \%)$ and station $3(80.3 \%)$, insect larvae were least recorded at the three stations.

\section{Relationship between phytoplankton and zooplankton abundance}

Generally, the percentages composition of the zooplankton in the entire lake were shore $(43.8 \%)>$ surface $(38.9 \%)>$ bottom $(17.3 \%)$ (Table 2) while for phytoplankton they were shore $(29.5 \%)<$ surface $(32.3 \%)<$ bottom $(38.2 \%)$ (Table1). The relationship in the abundance of the two groups of organism (phytoplankton and zooplankton) was observed to be inversed. The community of zooplankton on Lekan-Are was at its peak in the sunny month of February. The population began to decrease gradually along the months of the year until the least population was reached in the month of August (Figure 2). 
Table 1: Numerical abundance (no/I) of phytoplankton in each of the different habitats (shore, surface and bottom).

\begin{tabular}{lcccc}
\hline Phytoplankton & Shore & Surface & Bottom & Entire lake \% \\
\hline Chlorophyceae & 3249 & 3140 & 3638 & 57.5 \\
Bacillariophyceae & 1105 & 1441 & 1746 & 24.5 \\
Cyanophyceae & 780 & 1026 & 1255 & 18.0 \\
Total & 5134 & 5608 & 6638 & 100 \\
Entire lake (\%) & 29.5 & 32.3 & 38.2 & 100 \\
\hline
\end{tabular}

Table 2: Numerical abundance (No/L) of zooplankton in each of the different habitats (shore, surface and bottom).

\begin{tabular}{lcccc}
\hline Zooplankton & Shore & Surface & Bottom & Entire lake \% \\
\hline Cladocera & 410 & 351 & 438 & 10.8 \\
Copepoda & 4065 & 3587 & 1292 & 80.3 \\
Rotifera & 381 & 389 & 197 & 8.7 \\
Insect larvae & 20 & 9 & 0 & 0.2 \\
Total & 4876 & 4336 & 1927 & 100 \\
Entire lake (\%) & 43.8 & 38.9 & 17.3 & 100 \\
\hline
\end{tabular}

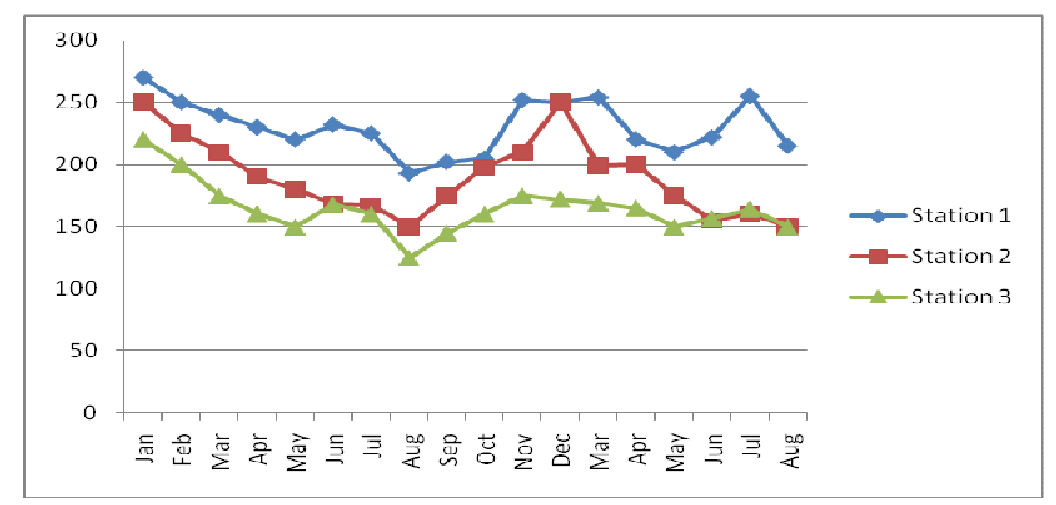

Figure 1: Monthly variation in mean values of the numerical density (nos/l) of phytoplankton at Lekan Are Lake, Nigeria.

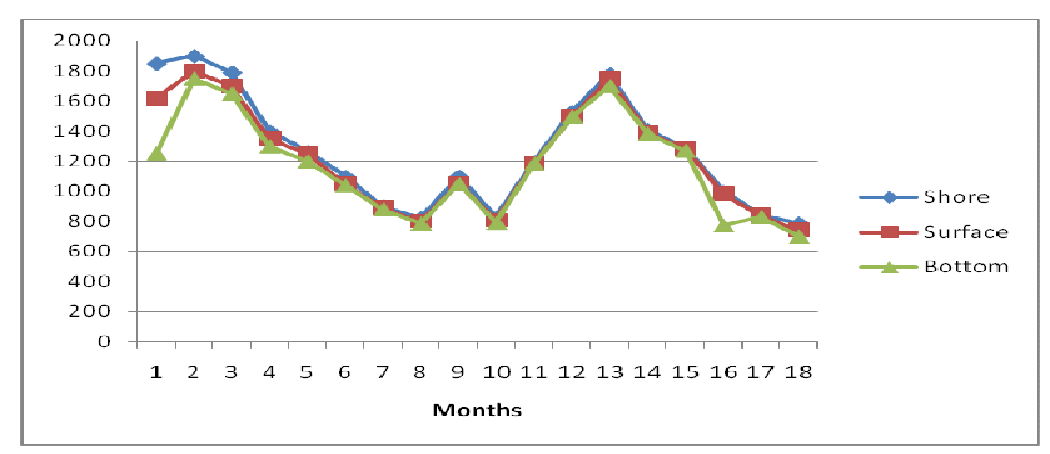

Figure 2: Monthly variation in mean values of the numerical density of Zooplankton (no/l) at Lekan Are Lake, Nigeria. 


\section{DISCUSSION}

The high phytoplankton density observed during the months of January to June may be due to high sunlight (Ikenweiwe, 2005). These are periods of high temperature which often aid high photosynthesis. It was also observed to be lowest in the rainy months of July - September. In November, which is the period of extreme cold and harmattan, the density of plankton also correspond to that of the raining season. According to Karlman (1982), seasonal mixing of the lake and river water of varying turbidity changes the optical characteristics of lake water and consequently affects phytoplankton production. The annual flood pattern is therefore the most important factor regulating phytoplankton production in the lake. January, February and March had higher concentration / abundance of phytoplankton and these months coincided with the period of higher temperature. This is in relation to the findings of Offem et al. (2011) who reported that monthly distribution of zooplankton at the water surface showed highest percentage occurrence in the months of April and November while the lowest was in September and December.

Ikenweiwe, and Otubusin (2005) confirmed that high water temperature resulted in greater species diversity of phytoplankton in Oyan Lake. This was in agreement with the reports of NIFFR (1999) and Ikenweiwe (2005) on lakes and river systems. Zooplankton abundance of the river system was poor in comparison with the lake. This is characteristics of river systems with shallow and high current velocity (NIFFR, 1999).

The Cladocerans followed the Copepoda in domination. This is in agreement with the findings of Adeniji and Ovie (1981) and NIFFR (1991) on the Copepoda and Cladocerans population of Asa and Agba reservoirs. Total zooplankton concentrations were highest at the inlet (station 1) compared to the other stations and least at station 3- dam site. This is in agreement with NIFFR (1991) which states that zooplankton population was always highest at the inlet station compared to those at the midlake and the outlet. At the different habitats sampled, it was observed that the population of the zooplankton was highest at the bottom water and least at the shore. This was in contrast to the observation of Paturej (2009) who reported that both the abundance and biomass of zooplankton were considerably higher in the middle part of lakes (as observed on Lake Łebsko) and in the littoral zone as observed on lake Gardnand and lake Jamno) than at the inflow of rivers. This contrast may be as a result of the migration activities of plankton which could be diurnal and seasonal.

Since the abundance of phytoplankton was higher during the dry season months, which was the period of higher temperature, it corroborated that sunlight (solar energy) is a pre-requisite for photosynthesis. There was an increased relationship between phytoplankton and zooplankton abundance.

Throughout the period of sampling the Chlorophycea and the Copepoda dominated the plankton community at the shore, surface and bottom at the inlet-mid-lake and outlet. This was in contrast with Ezekiel et al. (2011) where Bacillariophyceae was found to dominate $(41.9 \%)$ in Sombreiro river followed by Chlorophyceae $(32.6 \%)$, this is because two different water bodies were involved (lake and river).

\section{REFERENCES}

Adeniji HA, Ovie SI. 1981. Study of the abundance and distribution of Zooplankton in Asa Lake, Nigeria Kaiji Lake Research Institute Annual Report, $1-4$.

Anene A. 2003. Techniques in hydrobiology. In Research Techniques in Biological and Chemical Sciences, Eugene NO and OO Julian (Eds). Springfield Publishers; 174189.

Azionu BC. 2001. Linmological research in Nigeria: Some perspectives. Proceedings of the annual conference of Fisheries Society of Nigeria (FISON), 260-266.

Conde DS, Bonita L, Aubriot R, De Leon, Pintos W. 2007. Relative contribution of 
planktonic and benthic microalgae production in a Eutrophic Coastal Lagoon of South America. J. Limnol., 78: 207212.

Davies OA, Abowei JFN, Tawari CC. 2009. Phytoplankton community of Elechi Creek, Niger Delta, Nigeria - A nutrient polluted tropical creek. Am. J. Appl. Sci., 6(6): 1143-1152.

Ezekiel EN, Ogamba EN, Abowei JFN. 2011. Phytoplankton composition and abundance in Sombreiro River Niger Delta, Nigeria. Current Research Journal of Biological Sciences, 3(3): 229-233.

Ikenweiwe NB. 2005. Limnology, plankton abundance in relation to fish production in Oyan Lake, Southwestern Nigeria. $\mathrm{PhD}$. Thesis, Department of Aquaculture and Fisheries management, University of Agriculture Abeokuta Nig. 235pp.

Ikenweiwe NB, Otubusin SO. 2007. Some aspects of Limnology, fish and plankton distribution and abundance in Oyan Lake, Southwestern Nigeria. Applied Tropical Agric., 12(2): 60-69.

Karlman SG. 1982. The annual food regime as a regulating mechanism for phytoplankton in Kainji Lake, Nigeria. Hydrobiologia, 86: 93-99.

NIFFR 1991. Environmental impact Assessment of the proposed Zungeru Hydro-Electric power project in Niger State, Nigeria A report prepared by National Institute of Freshwater Fisheries
Research, New Bussa, Nigeria; Commissioned by the National Electron Power Authority (NEPA) PMB 12030, Lagos, pp. 31-74.

NIFFR. 1999. Post impoundment fisheries survey of Asa and Agba Reservoirs, Ilorin Kwara state; Nigeria A report prepared by National Institute of Freshwater Fisheries Research, New Bussa, Nigeria.

Offem BO, Ayotunde EO, Ikpi GU, Ochang SN, Ada FB. 2011. Influence of seasons on water quality, abundance of fish and plankton species of Ikwori Lake, SouthEastern Nigeria. Fisheries and Aquaculture Journal, 13: 1-18.

Ogun Osun River Basin Development Authority. 1998. Ogun Oshun River Basin development Authority. What it is, what it does, how it works. O-ORBDA Flyer, 5 p.

Paturej E. 2009. A zooplankton-based study of coastal lakes. Baltic Coastal Zone 13(2): 25-32.

Townsend CR, Harper JD, Begon M. 2000. Essentials of Ecology (3rd Edn). Blackwell Science: London, U.K. 